\title{
Stabilization of cyclin D1 mRNA via the phosphatidylinositol 3-kinase pathway in MCF-7 human breast cancer cells
}

\author{
B Dufourny, H A A M van Teeffelen, I H L Hamelers, \\ J $\mathbf{S}$ Sussenbach and $\mathbf{P}$ H Steenbergh
}

Utrecht Graduate School of Developmental Biology, Laboratory for Physiological Chemistry, Utrecht University, PO Box 80042,3508 TA Utrecht,
The Netherlands
(Requests for offprints should be addressed to P H Steenbergh; Email: P.H.Steenbergh@med.uu.nl)

\begin{abstract}
Treatment of quiescent MCF-7 human breast cancer cells with either the polypeptide growth factors insulin-like growth factor-I (IGF-I) or epidermal growth factor (EGF), the steroid hormone estradiol (E2) or the phorbol ester 12-O-tetradecanoylphorbol-13-acetate (TPA) results in increased steady-state levels of cyclin D1 mRNA and protein. Unexpectedly, this elevation of cyclin D1 expression by all of these agents is inhibited by the specific phosphatidylinositol 3-kinase (PI3-K) inhibitor LY294002. Since transcriptional activation of the cyclin D1 promoter by EGF, E2 and TPA is independent of
\end{abstract}

PI3-K activity, these findings suggest a post-transcriptional role for PI3-K in the regulation of cyclin D1 expression. Here we show that inhibition of PI3-K by LY294002 decreases the half-life of the $4.5 \mathrm{~kb}$ cyclin D1 mRNA species. In contrast, the stability of the $1.5 \mathrm{~kb}$ cyclin D1 mRNA is not affected by PI3-K inhibition. PI3-Kmediated stabilization of mRNA is not a general phenomenon, since other rapidly regulated and unstable mRNAs, such as those encoding $\mathrm{c}-f o s, \mathrm{c}-j u n$ and $\mathrm{c}-m y c$, are not stabilized upon activation of the PI3-K signaling pathway. Journal of Endocrinology (2000) 166, 329-338

\section{Introduction}

Orderly progression through the eukaryotic cell cycle is regulated by the activity of protein complexes consisting of a regulatory subunit called cyclin and a catalytic subunit, the cyclin-dependent kinase (cdk). Expression of the different cyclins is strictly orchestrated, so that each cyclin is only present during a specific time frame of the cell cycle (Nigg 1995). The first cyclins to appear when quiescent cells re-enter the cycle after growth-factor stimulation are the D-type cyclins (D1, D2 and D3). These cyclins bind to, and thereby activate, cdk4 and cdk6, which then phosphorylate the retinoblastoma protein $(\mathrm{pRb})$. This phosphorylation leads to release of gene E2 promoterspecific factor (E2F) transcription factors from $\mathrm{pRb}$, and in transcriptional activation of genes, containing E2Fsensitive promoters (Müller 1995, Weinberg 1995, Sanchez \& Dynlacht 1996). Overexpression of cyclin D1, caused by genomic amplification, chromosomal translocation, increased mRNA stability or enhanced protein half-life, has been shown to be a feature of several human cancers, such as leukemias, breast tumors and sarcomas (Withers et al. 1991, Seto et al. 1992, Lebwohl et al. 1994, Welcker et al. 1996, Hosokawa et al. 1998). On the other hand, inhibition of cyclin D1 expression by microinjection of antibodies or antisense probes increases the length of the
G1 phase and inhibits proliferation (Filmus et al. 1994, Liu et al. 1995). These data establish cyclin D1 as an important regulator of G1 phase progression. The MCF-7 cell line is a human epithelial breast cancer cell line with the characteristic that serum-starved cells enter the cell cycle upon the sole addition of insulin-like growth factor-I (IGF-I) (van der Burg et al. 1988, Karey \& Sirbasku 1988). Stimulation with IGF-I leads to enhanced expression of cyclin D1, hyperphosphorylation of $\mathrm{pRb}$, DNA synthesis and cell division (Dufourny et al. 1997). Since upregulation of cyclin D1 is the first event in this process, and overexpression of cyclin D1 has been shown to be sufficient for growth of MCF-7 cells under low-serum conditions (Zwijsen et al. 1996), the increase in cyclin D1 levels seems to be the essential step in mitogenic IGF-I signaling. The signaling pathways that are activated by IGF-I, and their role in transducing the mitogenic stimulus to the cell nucleus, have been partly unraveled. Binding of IGF-I to its receptor leads to autophosphorylation of the receptor and activation of its tyrosine kinase activity. An important substrate for the receptor is insulinreceptor substrate-1 (IRS-1) (Izumi et al. 1987, Shemer et al. 1987) which, after phosphorylation, serves as a docking site for multiple src homology-2 (SH2)-domain containing proteins, such as $\mathrm{p} 85$, the regulatory subunit of phosphatidylinositol 3-kinase (PI3-K) (Myers et al. 1992, 
Backer et al. 1993), and the guanine-nucleotide exchange factor Grb2/Sos (Baltensperger et al. 1993, Skolnik et al. $1993 a, b)$. Among the downstream targets of PI3-K are protein kinase B (PKB) (Burgering \& Coffer 1995), p70 ${ }^{\mathrm{S} 6 \mathrm{~K}}$ (Cheatham et al. 1994), and the small GTPases Rho, Rac and cdc42 (Chou \& Blenis 1996). On the other hand, interaction of the receptor with Grb2/Sos results in activation of the ras-raf-MAP (mitogen-activated protein) kinase pathway (Cobb \& Goldsmith 1995). In previous work (Dufourny et al. 1997), we showed that in MCF-7 cells the IGF-I induced rise in cyclin D1 steady-state levels is inhibited by the specific PI3-K inhibitors LY294002 (Vlahos et al. 1994) and wortmannin (Arcaro \& Wymann 1993). The MAP kinase/ERK kinase 1 (MEK1) inhibitor PD098059 (Dudley et al. 1995) does not affect cyclin D1 mRNA and protein expression induced by IGF-I. This suggests that in MCF-7 cells proliferative IGF-I signaling is dependent on PI3-K activity, and that the MAP kinases are not involved in this process. Here we investigate the mechanism by which PI3-K regulates the expression of cyclin D1. Theoretically, the observed increase in cyclin D1 levels upon IGF-I stimulation may be caused by transcriptional activation, by increased mRNA stability, by enhanced translation efficiency and by increased protein half-life. Contradictory reports on this issue have appeared in the literature. In NIH3T3 fibroblasts, it was found that rapamycin, an inhibitor of $\mathrm{p} 70^{\mathrm{S} 6 \mathrm{~K}}$ (Price et al. 1992), reduces the cyclin D1 mRNA half-life (Hashemolhosseini et al. 1998). This would suggest a role for a PI3-K-dependent signaling route in the regulation of cyclin D1 mRNA stability. In contrast, it has been reported that inhibition of PI3-K activity reduces the efficiency of translation of cyclin D1 mRNA in MCF-7 and MCF-10A cells (Muise-Helmericks et al. 1998). Here we show that activation of the PI3-K pathway stabilizes the $4.5 \mathrm{~kb}$ cyclin D1 mRNA, whereas the stability of the $1.5 \mathrm{~kb} \mathrm{mRNA}$ is not influenced. The observed stabilization of the $4.5 \mathrm{~kb}$ mRNA species is not a general phenomenon, since other rapidly regulated and unstable mRNAs, such as those encoding c-fos, c-jun and $\mathrm{c}-m y c$ are not stabilized upon activation of the PI3-K pathway.

\section{Materials and Methods}

\section{Reagents}

LY294002 was purchased from Biomol Research Laboratories Inc. (Plymouth Meeting, PA, USA). Cycloheximide was from Sigma (St Louis, MO, USA) and actinomycin D was supplied by Boehringer Mannheim GmbH (Mannheim, Germany). The anti-cyclin D1 antibody H-295 was purchased from Santa Cruz Biotechnology (Santa Cruz, CA, USA). The cyclin D1 promoter-luciferase construct was kindly provided by Dr Rolf Müller (Marburg, Germany).

\section{Hybridization probes}

The cyclin D1 probe, a kind gift from Dr D Beach (Cold Spring Harbor, NY, USA), is a 1325 bp PCR product encoding the entire human cyclin D1 cDNA sequence (Xiong et al. 1991). The c-fos probe is a $1800 \mathrm{bp}$ EcoRIXhol human c-fos cDNA fragment. The c-jun probe is a $1350 \mathrm{bp}$ EcoRI-BamHI human c-jun cDNA fragment. The c-myc probe is a $800 \mathrm{bp}$ HindIII-ClaI human c-myc cDNA fragment. The 28S rRNA oligonucleotide has the following sequence: 5'-AAC GAT CAG AGT AGT GGT ATT TCA CC-3'.

\section{Cell culture}

MCF-7 human breast cancer cells were cultured in Dulbecco's Minimal Essential Medium/Ham's F12 medium (1:1), supplemented with $5 \%$ fetal calf serum, $300 \mu \mathrm{g} / \mathrm{ml}$ glutamine, $100 \mathrm{IU} / \mathrm{ml}$ penicillin and $100 \mu \mathrm{g} / \mathrm{ml}$ streptomycin. Cells were made quiescent by culturing them for $24 \mathrm{~h}$ in phenol red-free medium containing 5\% dextran-coated charcoal-treated serum, followed by a $24 \mathrm{~h}$ incubation in phenol red-free, serumfree medium, supplemented with $0 \cdot 2 \%$ BSA, $10 \mu \mathrm{g} / \mathrm{ml}$ transferrin and $30 \mathrm{nM}$ sodium selenite.

\section{PKB kinase assay}

Cells were washed in PBS and lysed in IP buffer $(50 \mathrm{mM}$ Tris- $\mathrm{HCl} \mathrm{pH} 7 \cdot 5,100 \mathrm{mM} \mathrm{NaCl}, 50 \mathrm{mM} \mathrm{NaF}, 5 \mathrm{mM}$ EDTA, $1 \%$ Triton X-100, $10 \mu \mathrm{g} / \mathrm{ml}$ leupeptin, $2 \mu \mathrm{g} / \mathrm{ml}$ aprotinin, $0 \cdot 1 \mathrm{mM} \mathrm{Na}_{3} \mathrm{VO}_{4}$ ). Lysates were pre-cleared by incubation with $25 \mu \mathrm{l} 10 \%$ protein A-agarose beads precoupled to normal rabbit serum for $15 \mathrm{~min}$ at $4{ }^{\circ} \mathrm{C}$. Lysates were then incubated with $70 \mu \mathrm{l} 10 \%$ protein $\mathrm{A}$-agarose beads, pre-coupled to anti-PKB antibody for $2 \mathrm{~h}$ at $4{ }^{\circ} \mathrm{C}$. Beads were washed twice in IP buffer, twice in $50 \mathrm{mM}$ Tris- $\mathrm{HCl} \mathrm{pH} 7 \cdot 5,10 \mathrm{mM} \mathrm{MgCl} 2,0.5 \mathrm{M} \mathrm{LiCl}, 200 \mu \mathrm{M}$ $\mathrm{Na}_{3} \mathrm{VO}_{4}$, and once in $50 \mathrm{mM}$ Tris- $\mathrm{HCl} \mathrm{pH} 7 \cdot 5,10 \mathrm{mM}$ $\mathrm{MgCl}_{2}, 200 \mu \mathrm{M} \mathrm{Na} \mathrm{VO}_{4}$. Beads were then resuspended in a $25 \mu$ l kinase mix $(50 \mathrm{mM}$ Tris $-\mathrm{HCl} \mathrm{pH} 7 \cdot 5,10 \mathrm{mM}$ $\mathrm{MgCl}_{2}, 1 \mathrm{mM}$ dithiothreitol (DTT), $50 \mu \mathrm{M} \mathrm{ATP}$ ) supplemented with $5 \mu \mathrm{g}$ histone $2 \mathrm{~B}$ and $5 \mu \mathrm{Ci}\left[\gamma-{ }^{32} \mathrm{P}\right] \mathrm{ATP}$ per sample. The mixture was incubated for $20 \mathrm{~min}$ at $30^{\circ} \mathrm{C}$, after which the reaction was stopped with $8 \mu \mathrm{l}$ of $4 \times$ sample buffer $(200 \mathrm{mM}$ Tris- $\mathrm{HCl}$ pH 6.8, $400 \mathrm{mM}$ DTT, 8\% SDS, 0.4\% bromophenol blue, 40\% glycerol). The suspension was boiled and centrifuged, and the supernatant was run on a $15 \%$ SDS-polyacrylamide gel. The gel was dried and exposed to X-ray film (Fuji, Tokyo, Japan).

\section{Western blotting}

Experiments were performed in six-well plates or in $25 \mathrm{~cm}^{2}$ flasks. Cells were washed in ice-cold PBS and lysed in $100 \mu \mathrm{l}$ lysis buffer per well or $200 \mu \mathrm{l}$ per flask 
(25 mM Tris-phosphate $\mathrm{pH} 7 \cdot 8,15 \%$ glycerol, $1 \%$ Triton $\mathrm{X}-100)$. Lysates were cleared by centrifugation and protein concentrations were determined using the BCA protein assay (Pierce, Rockford, IL, USA). Equal amounts of protein $(5 \mu \mathrm{g})$ were size-separated in a $12.5 \%$ SDSpolyacrylamide gel and transferred to nitrocellulose. The membrane was stained with Ponceau S (Sigma), to check for equal loading, and blocked in 1\% BSA for $1 \mathrm{~h}$. Incubation with the anti-cyclin D1 antibody was performed overnight at $4{ }^{\circ} \mathrm{C}(1: 2500$ in $0.1 \%$ BSA in TBST $(150 \mathrm{mM} \mathrm{NaCl}, 10 \mathrm{mM}$ Tris- $\mathrm{HCl} \mathrm{pH}$ 8.0, 0.2\% Tween 20)). The membrane was washed in TBST and exposed to horseradish peroxidase-coupled anti-rabbit antibody for $1 \mathrm{~h}(1: 8000$ in TBST). For detection, the Enhanced Chemiluminescence (ECL) system (NEN Life Science Products Inc., Boston, MA, USA) was used.

\section{Northern blotting}

Experiments were performed in $25 \mathrm{~cm}^{2}$ flasks. Cells were washed in ice-cold PBS and lysed in RNAzol B (Biotecx Laboratories Inc., Houston, TX, USA). Total RNA was extracted and precipitated according to the manufacturer's instructions and dissolved in sterile water. Equal amounts of RNA $(10 \mu \mathrm{g})$ were glyoxylated in $50 \% \mathrm{Me}_{2} \mathrm{SO}$ and size-separated by electrophoresis in a $0 \cdot 8 \%$ agarose gel. RNA was transferred to a nylon membrane (Genescreen, NEN Life Science Products) and cross-linked to the membrane by u.v. irradiation. The blots were prehybridized for several hours at $42{ }^{\circ} \mathrm{C}$ in $50 \%$ deionized formamide, $1 \mathrm{M} \mathrm{NaCl}, 50 \mathrm{mM}$ Tris $-\mathrm{HCl} \mathrm{pH} 7 \cdot 5,0 \cdot 2 \%$ BSA, $0 \cdot 2 \%$ polyvinylpyrrolidone, $0 \cdot 2 \%$ Ficoll $400,0 \cdot 1 \%$ sodium pyrophosphate, $1 \%$ SDS, $10 \%$ dextran sulfate and $200 \mu \mathrm{g} / \mathrm{ml}$ denatured herring sperm DNA. Hybridization was performed overnight in the same solution to which the specific ${ }^{32} \mathrm{P}$-labeled cDNA probes $\left(10^{6}\right.$ c.p.m. $\left./ \mathrm{ml}\right)$ were added. Double-stranded probes were labeled by random priming using Rediprime (Amersham Life Sciences Inc., Little Chalfont, UK). The single-stranded 28S rRNA oligonucleotide was end-labeled using $\left[\alpha-{ }^{32} \mathrm{P}\right] \mathrm{dATP}$ and T4 polynucleotide kinase. Membranes were exposed to X-ray film (Fuji).

\section{Transfections}

Cells were seeded in six-well plates $\left(10^{6}\right.$ cells/plate $)$ one day before transfection. Transfections were done using the DAC30 transfection reagent (Eurogentec, Seraing, Belgium). Per well, $3 \mu \mathrm{g}$ DAC30, $0.5 \mu \mathrm{g}$ cyclin D1 promoter-luciferase construct and $0 \cdot 1 \mu \mathrm{g}$ cytomegalovirus (CMV)-lacZ-encoding plasmid was used. For each well, DNA was diluted in $500 \mu \mathrm{l}$ HBS buffer $(150 \mathrm{mM} \mathrm{NaCl}$, $20 \mathrm{mM}$ Hepes, $\mathrm{pH}$ 7·4). DAC30 was diluted in an equal volume of HBS. The DNA- and DAC30 dilutions were then combined, gently mixed and left at room temperature for $20 \mathrm{~min}$. Immediately before transfection, the medium on the cells was refreshed using $1 \mathrm{ml}$ per well. The DNA/DAC30 mixture was now added dropwise to the cells under continuous swirling, after which they were incubated for $3 \mathrm{~h}$ at $37^{\circ} \mathrm{C}$. After transfection, the transfection mixture was replaced by phenol red-free, serumfree medium, with or without LY294002, for $24 \mathrm{~h}$.

\section{Luciferase assay}

Approximately $24 \mathrm{~h}$ after transfection, the culture medium was removed and the cells were washed in ice-cold PBS and lysed in $100 \mu \mathrm{l}$ lysis buffer $(25 \mathrm{mM}$ Tris-phosphate $\mathrm{pH} 7 \cdot 8,15 \%$ glycerol, $1 \%$ Triton X-100, 1 mM DTT and $8 \mathrm{mM} \mathrm{MgCl} 2$ ) per well. Lysates were centrifuged for $2 \mathrm{~min}$ at 14000 r.p.m. and $25 \mu \mathrm{l}$ supernatant were used in the assay. Luciferase activities were measured using a Lumat LB9507 luminometer (EG \& G Berthold, Bad Wildbad, Germany), and were corrected for transfection efficiency using $\beta$-galactosidase activity from the cotransfected lac $Z$ plasmid as an internal standard.

\section{Lac $Z$ assay}

Of the lysate, $10 \mu \mathrm{l}$ were mixed with $221 \mu \mathrm{l} 100 \mathrm{mM}$ sodium phosphate buffer ( $\mathrm{pH} 7 \cdot 4), 66 \mu \mathrm{l}$ o-nitrophenyl- $\beta$ D-galactopyranoside (ONPG, $4 \mathrm{mg} / \mathrm{ml}$ ) and $3 \mu \mathrm{l} 4.5 \mathrm{M}$ $\beta$-mercaptoethanol/ $0 \cdot 1 \mathrm{M} \mathrm{MgCl}$. After incubation for 30-60 min at $37^{\circ} \mathrm{C}$, reactions were stopped with $500 \mu \mathrm{l}$ $0.5 \mathrm{M} \mathrm{Na}_{2} \mathrm{CO}_{3}$. Reaction mixtures were extracted with $500 \mu \mathrm{l}$ chloroform/isoamylalcohol (19:1). After $2 \mathrm{~min}$ of centrifugation at 14000 r.p.m., the absorbance at $420 \mathrm{~nm}$ of the upper phase was measured spectrophotometrically.

\section{Results}

Transcriptional activation of cyclin D1 by IGF-I, but not by TPA and E2, is mediated by PI3-K

We have previously shown that addition of $10 \mathrm{ng} / \mathrm{ml}$ IGF-I to the medium of serum-starved MCF-7 cells increases cyclin D1 mRNA and protein levels. This increase is inhibited by the PI3-K inhibitor LY294002, indicating that PI3-K activity is needed for the observed rise in cyclin D1 level. We have extended this observation by showing activation of the cyclin D1 promoter by constitutively active PI3-K mutants as well as by Rac and cdc42, two related small GTPases functioning downstream of PI3-K (submitted for publication). We then investigated whether LY294002-mediated inhibition is also observed with other agents known to increase cyclin D1 levels in these cells. As demonstrated in Fig. 1A, the phorbol ester 12-O-tetradecanoylphorbol-13-acetate (TPA, $100 \mathrm{ng} / \mathrm{ml})$, the steroid hormone E2 $(1 \mathrm{nM})$ and epidermal growth factor (EGF, $40 \mathrm{ng} / \mathrm{ml}$ ), like IGF-I, increase cyclin D1 protein levels when added to serumdeprived MCF-7 cells. TPA, a strong growth inhibitor for 

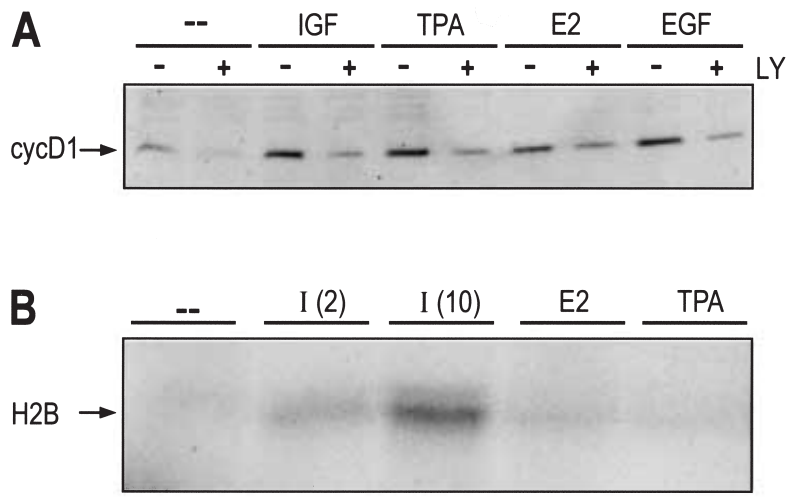

Figure 1 Effect of PI3-K inhibition on cyclin D1 protein induction. A. Serum-starved MCF-7 cells were stimulated with $40 \mathrm{ng} / \mathrm{ml} \mathrm{IGF-I,}$ $100 \mathrm{ng} / \mathrm{ml} \mathrm{TPA}, 1 \mathrm{nM}$ E2 or $40 \mathrm{ng} / \mathrm{ml}$ EGF with or without pre-incubation with $50 \mu \mathrm{M}$ LY294002 for $10 \mathrm{~min}$. Cells were harvested $5 \mathrm{~h}$ after stimulation and cyclin D1 protein levels were analyzed by Western blotting. B. Activation of PKB by several stimuli. Serum-starved cells were stimulated with 2 or $10 \mathrm{ng} / \mathrm{ml}$ IGF-I, $100 \mathrm{ng} / \mathrm{ml} \mathrm{TPA}$ or $1 \mathrm{nM}$ E2 for $7 \mathrm{~min}$. Cells were lysed, PKB was immunoprecipitated and its kinase activity was determined using histone $2 \mathrm{~B}$ as a substrate.

MCF-7 cells because of its induction of large amounts of $\mathrm{p} 21^{\text {waf1 }}$ (Dufourny et al. 1997), has been shown to enhance cyclin D1 promoter activity via an activating protein (AP)-1 response element at position -954 relative to the transcription start site (Albanese et al. 1995, Watanabe et al. 1996). Activation of AP-1 elementbinding transcription factors, e.g. c-fos and c-jun, is thought to result from activation of protein kinase $\mathrm{C}$, and subsequent induction of the raf-MEK1-MAP kinase signaling cascade by TPA. The same is true for EGF, which is also a strong activator of the MAP kinases. E2 has been shown to activate the cyclin D1 promoter through an Estrogen Response Element (ERE) located more than $940 \mathrm{bp}$ upstream of the transcription start site (Altucci et al. 1996). Surprisingly, the increase in cyclin D1 protein levels caused by TPA or E2 as well as that by EGF is inhibited, as in the case of IGF-I, by the prior addition of LY294002 $(50 \mu \mathrm{M})$ to the medium of serum-starved MCF-7 cells (Fig. 1A). The signaling pathways activated by TPA and E2 have been extensively studied in recent years. These studies indicate that activation of PI3-K by these agents is not a generally accepted concept. To determine whether TPA and/or E2 is/are able to enhance PI3-K activity in MCF-7 cells, we measured the activity of PKB/Akt-1, a well-documented downstream target of PI3-K (Burgering \& Coffer 1995). Serum-starved MCF-7 cells were incubated with 2 or $10 \mathrm{ng} / \mathrm{ml}$ IGF-I, $1 \mathrm{nM}$ E2 or $100 \mathrm{ng} / \mathrm{ml} \mathrm{TPA}$. After $7 \mathrm{~min}$ at $37^{\circ} \mathrm{C}$, cells were lysed. PKB was immunoprecipitated and its kinase activity was measured using histone $2 \mathrm{~B}$ as a substrate. Whereas IGF-I in relatively low concentrations already activates $\mathrm{PKB}$, no activity above the level found in untreated, serum-starved

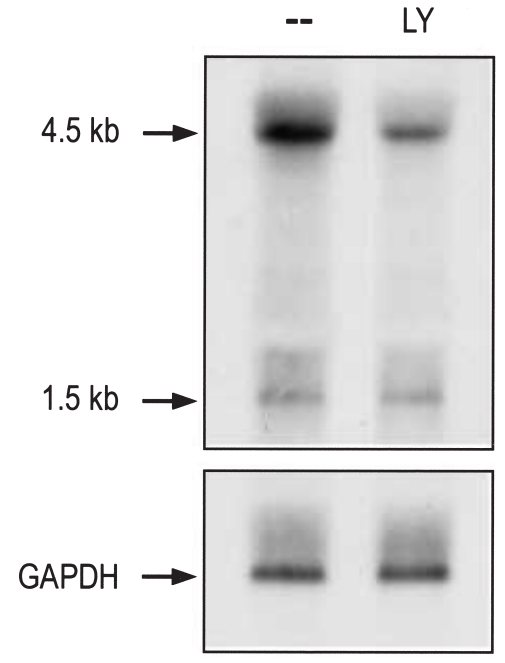

Figure 2 Effect of PI3-K inhibition on cyclin D1 mRNA steady-state levels in quiescent cells. Serum-starved MCF-7 cells were treated with $50 \mu \mathrm{M}$ LY294002. Cells were harvested $4 \mathrm{~h}$ after the addition and cyclin D1 mRNA levels were analyzed by Northern blotting. Equal loading was checked for by hybridization of the Northern blot to a glyceraldehyde 3-phosphate-dehydrogenase (GAPDH) probe.

cells was detected after treatment with TPA or E2 (Fig. 1B). Conceivably, an essential basal transcription factor might be controlled by PI3-K in such a way that cyclin D1 transcription is turned off when PI3-K is inhibited by LY294002. However, in transient transfection assays, employing a -1170 to +141 cyclin D1 promoterluciferase construct, no effect of LY294002 on the basal activity of the promoter was observed (data not shown). The clear effect of LY294002 on cyclin D1 levels observed after treatment with IGF-I, TPA and E2, combined with the lack of PI3-K activition by TPA and E2, thus strongly suggests the existence of an efficient PI3-Kdependent mechanism controlling cyclin D1 levels post-transcriptionally.

\section{PI3-K activity is required for cyclin D1 mRNA stabilization}

Theoretically, the observed enhancing effect of PI3-K activity on cyclin D1 levels, which is independent of the presence of transcriptional activators, may be explained by stabilization of the transcript, enhancement of the rate of translation, or stabilization of the cyclin D1 protein itself. As illustrated in Fig. 2, we reproducibly observed a considerable drop in the steady-state level of the $4.5 \mathrm{~kb}$ cyclin D1 mRNA in serum-starved cells during a $4 \mathrm{~h}$ period after addition of LY294002, whereas the amount of the $1.5 \mathrm{~kb}$ mRNA species remained unchanged. This observation suggests that inhibition of PI3-K results in destabilization of cyclin D1 mRNA and that the long mRNA species is more sensitive to the destabilizing effect. 


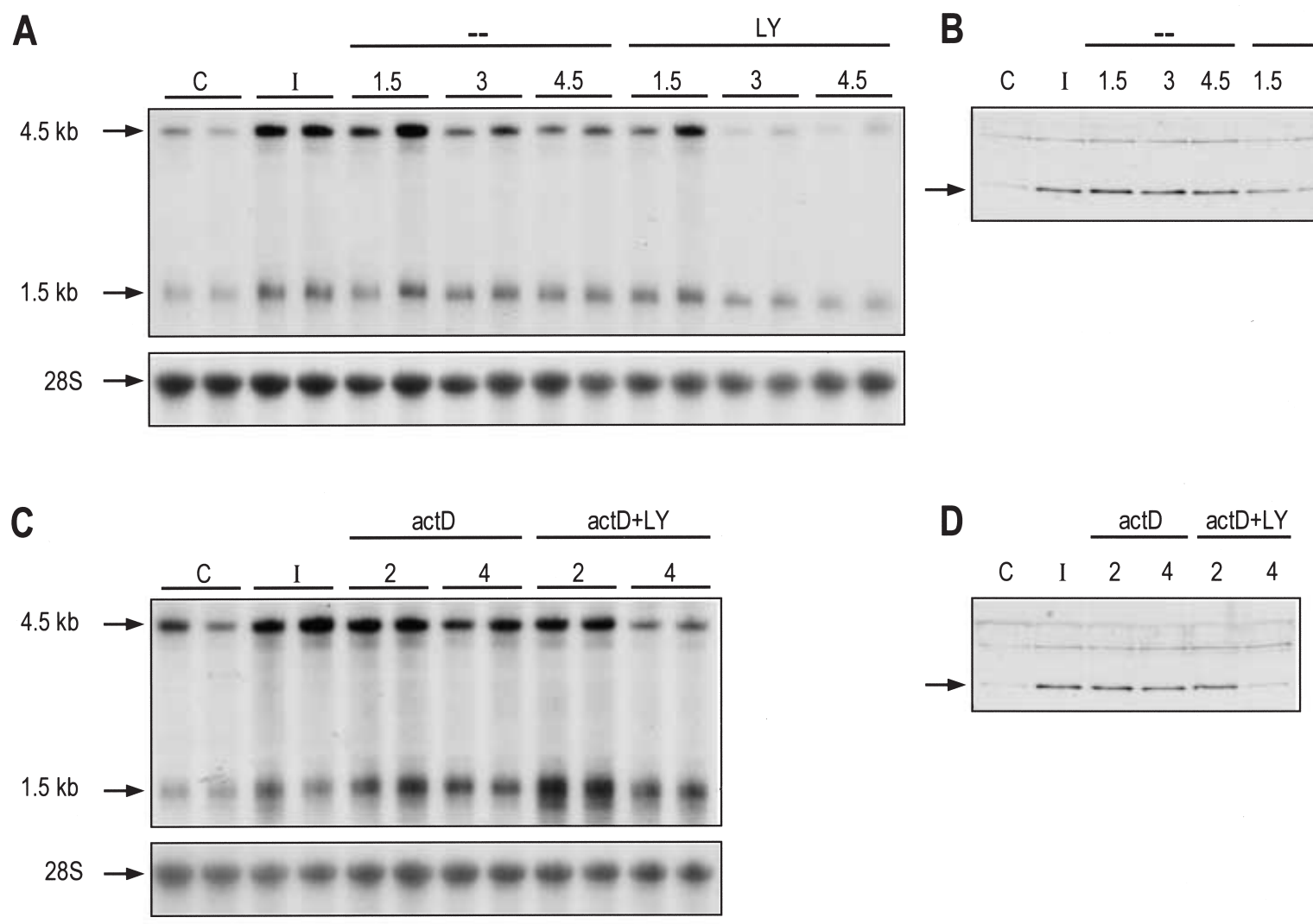

Figure 3 Effect of PI3-K inhibition on decay of cyclin D1 mRNA and protein. Serum-starved cells were stimulated for $4 \mathrm{~h}$ with $40 \mathrm{ng} / \mathrm{ml}$ IGF-I. After stimulation, cells were given fresh serum-free medium (A+B) or serum-free medium containing $20 \mu \mathrm{g} / \mathrm{ml}$ actinomycin D $(C+D)$ with or without $50 \mu \mathrm{M}$ LY294002. Cells were harvested at the indicated time points (in h) and cyclin D1 mRNA and protein levels were determined by Northern $(A+C)$ and Western $(B+D)$ blotting. All RNA samples are shown in duplicate, and equal loading was checked for by hybridization of the Northern blots to a $28 \mathrm{~S}$ rRNA specific oligonucleotide.

To test this hypothesis, we studied the decay of cyclin D1 mRNA in MCF-7 cells in the presence and absence of the PI3-K inhibitor. Quiescent cells were stimulated with IGF-I for $4 \mathrm{~h}$. After incubation, the cells were given fresh serum-free medium with or without $50 \mu$ M LY294002. Cells were harvested at the indicated time points and cyclin D1 mRNA and protein levels were analyzed (Fig. 3A and B). In the absence of LY294002, the levels of the $4.5 \mathrm{~kb}$ cyclin D1 mRNA were quite stable. Only a slight decrease in its steady-state level was observed during the course of the experiment. In contrast, in the presence of LY294002 the levels of the $4.5 \mathrm{~kb}$ mRNA dropped much more rapidly and were already below the basal steady-state level after $3 \mathrm{~h}$. The $1.5 \mathrm{~kb}$ mRNA level was more constant throughout the experiment, also in the presence of LY294002. The level of the short mRNA diminished only slightly after $3 \mathrm{~h}$ but this was insignificant when compared with the decrease in the level of the long mRNA. The rate of decay of the $4.5 \mathrm{~kb}$ mRNA corresponded quite well with what was seen in the corresponding Western blot analysis. The cyclin D1 protein level was rather constant over a $4.5 \mathrm{~h}$ period in the untreated cells, whereas a rapid decline was observed in cells treated with LY294002 (Fig. 3B).

\section{Cyclin D1 mRNA stabilization by PI3-K does not require} de novo transcription

To determine whether this PI3-K mediated stabilizing influence on the $4.5 \mathrm{~kb}$ cyclin D1 mRNA requires de novo transcription, we repeated the above experiment but included actinomycin D to inhibit transcription. After stimulation with IGF-I, the cells were given fresh serumfree medium containing $20 \mu \mathrm{g} / \mathrm{ml}$ actinomycin D with or without $50 \mu \mathrm{M}$ LY294002. Cells were harvested after 2 and $4 \mathrm{~h}$, and cyclin D1 mRNA and protein levels were determined. The results are shown in Fig. 3C and D. In agreement with the data in Fig. 3A and B, again in this experiment no difference in $\mathrm{mRNA}$ and protein levels in absence or presence of LY294002 was detected after $2 \mathrm{~h}$. However, after $4 \mathrm{~h}$ the decrease in the $4.5 \mathrm{~kb}$ cyclin D1 mRNA level, as well as in the protein level, was 

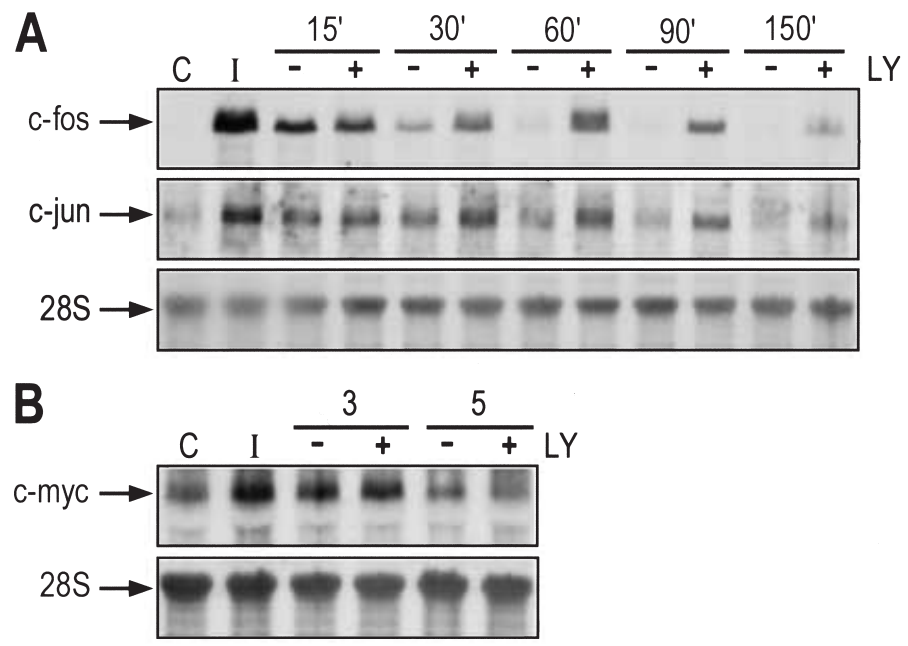

Figure 4 Effect of PI3-K inhibition on half-life of several early geneencoding mRNAs. A. Serum-starved MCF-7 cells were stimulated for $45 \mathrm{~min}$ with $10 \mathrm{ng} / \mathrm{ml} \mathrm{TPA}$. After stimulation, cells were given fresh serum-free medium with or without $25 \mu \mathrm{M}$ LY294002. Cells were harvested at the indicated time points (in min) and c-fos and c-jun mRNA levels were determined by Northern blotting. B. Quiescent cells were stimulated for $4 \mathrm{~h}$ with $20 \mathrm{ng} / \mathrm{ml} \mathrm{IGF-I,} \mathrm{after} \mathrm{which} \mathrm{the} \mathrm{cells} \mathrm{were} \mathrm{given}$ fresh serum-free medium with or without $50 \mu \mathrm{M}$ LY294002. Cells were harvested at the indicated time points (in h) and c-myc mRNA levels were analyzed by Northern blotting. Equal loading was checked for by hybridization of the Northern blots to a $28 \mathrm{~S}$ rRNA-specific oligonucleotide.

significantly stronger in the presence of LY294002 than in its absence. Again, the effect was much less pronounced if not absent for the $1.5 \mathrm{~kb}$ cyclin D1 mRNA species. These data indicate that the stabilizing effect of PI3-K activity on the long cyclin D1 mRNA does not require de novo transcription, since it is also observed in the presence of actinomycin D.

\section{Stabilization of $m R N A$ by PI3-K is specific for cyclin D1}

The $4.5 \mathrm{~kb}$ cyclin D1 mRNA species possesses about $3 \mathrm{~kb}$ 3 '-untranslated region ( $3^{\prime}$-UTR), containing a cluster of six AUUUA repeats within a region of 420 residues (Motokura et al. 1991). The $1.5 \mathrm{~kb}$ cyclin D1 mRNA only has about 200 residues in its $3^{\prime}$-UTR and lacks the AUUUA repeats. The AUUUA sequences are known as instability determinants (Ross 1995), and are present in many rapidly regulated transcripts (Henics et al. 1994, Mayo et al. 1995, Kastelic et al. 1996, Peng et al. 1996, Chagnovich \& Cohn 1997, Wang et al. 1997, Esnault et al. 1998). To determine whether other transcripts, containing AUUUA repeats in their $3^{\prime}-\mathrm{UTR}$, are influenced by PI3-K in the same way, we studied the effect of LY294002 on c-fos, c-jun and c-myc mRNA stability in MCF-7 cells. These early response gene-encoding transcripts all possess $3^{\prime}$-UTRs containing AUUUA repeats. The levels of $c-f o s$ and $c-j u n$ mRNA were induced by stimulation with $10 \mathrm{ng} / \mathrm{ml}$ TPA for $45 \mathrm{~min}$. After stimulation, cells were given fresh serum-free medium with or without $25 \mu$ M LY294002 and harvested at the indicated time points. The results are shown in Fig. 4A. TPA treatment dramatically increases the mRNA levels of both c-fos and c-jun. In the absence of LY294002, both mRNAs decay quite rapidly. Within $1 \mathrm{~h}$ their levels decrease to that of unstimulated cells. However, when LY294002 is present these mRNAs have a significantly longer half-life. After $2.5 \mathrm{~h}$ the levels of c-fos and c-jun mRNA are still clearly above the basal level in untreated, serum-starved cells. These data suggest that inhibition of PI3-K stabilizes these messengers and that PI3-K activity has a destabilizing influence. In Fig. 4B, the results are shown for c-myc mRNA. In this experiment, cells were stimulated for $4 \mathrm{~h}$ with IGF-I. After stimulation, cells were given fresh, serum-free medium with or without LY294002 and cells were harvested 3 and $5 \mathrm{~h}$ later. At both time points, no difference in c-myc mRNA levels was observed in the presence or absence of LY294002, suggesting that PI3-K activity does not influence c-myc mRNA stability. Although the mechanisms of these PI3-K-mediated effects are still completely unknown, these data indicate that the stabilizing influence of PI3-K on cyclin D1 mRNA is not a general phenomenon for all unstable mRNAs. 
A

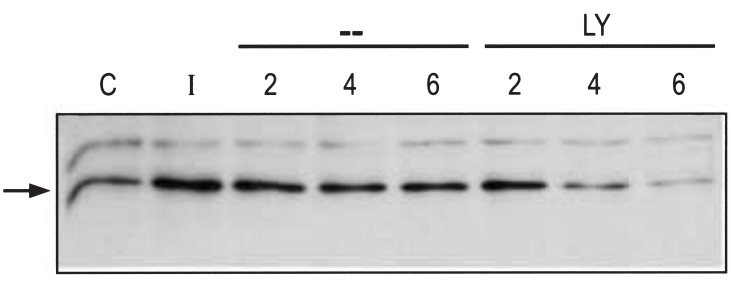

B

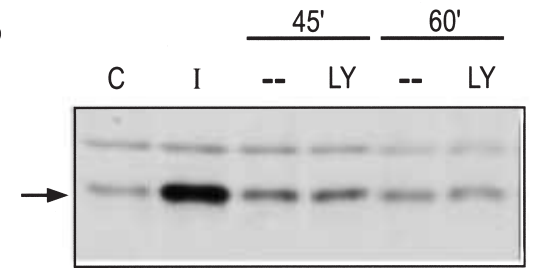

Figure 5 Decay of cyclin D1 protein after inhibition of transcription or translation. Quiescent MCF-7 cells were stimulated for $4 \mathrm{~h}$ with $20 \mathrm{ng} / \mathrm{ml} \mathrm{IGF-I.} \mathrm{After} \mathrm{stimulation,} 20 \mu \mathrm{g} / \mathrm{ml}$ actinomycin D (A) or $50 \mu \mathrm{g} / \mathrm{ml}$ cycloheximide (B) was added with or without $50 \mu \mathrm{M}$ LY294002 (LY). Cells were harvested at the indicated time points (in $\mathrm{h}$ for $\mathrm{A}$, in min for $\mathrm{B}$ ) and cyclin D1 protein levels were analyzed by Western blotting.

\section{PI3-K activity does not affect cyclin D1 protein stability}

In several experiments we observed that the decrease in steady state-levels in the presence of LY294002 was more pronounced for the cyclin D1 protein level than it was for the cyclin D1 mRNA level (see Fig. 3). Since we could not exclude from the previous experiments the possibility that PI3-K activity influences cyclin D1 protein stability in addition to mRNA stability, we also studied cyclin D1 protein levels in the presence of the translation inhibitor cycloheximide. Serum-starved MCF-7 cells were stimulated with $20 \mathrm{ng} / \mathrm{ml}$ IGF-I for $4 \mathrm{~h}$. After stimulation, $20 \mu \mathrm{g} / \mathrm{ml}$ actinomycin D or $50 \mu \mathrm{g} / \mathrm{ml}$ cycloheximide was added in combination with $50 \mu \mathrm{M}$ LY294002. Subsequently, cells were harvested at $2 \mathrm{~h}$ intervals and cyclin D1 protein levels were monitored by Western blotting. Figure 5A shows that, in agreement with the data in Fig. 3B, addition of actinomycin D alone does not affect cyclin D1 protein levels, no decrease being observed during the course of the experiment. In contrast, when LY294002 is present cyclin D1 protein levels drop significantly. After $4 \mathrm{~h}$, the level is already below that in quiescent cells. In contrast, in the presence of cycloheximide cyclin D1 protein levels drop to almost undetectable levels within $2 \mathrm{~h}$, even in the absence of LY294002, indicating that the protein is short-lived (data not shown). Thus an effect of LY294002, if any, on cyclin D1 protein stability could not be determined. Therefore, we repeated the above experiment but instead harvested the cells at much earlier time points. As can be seen in Fig. 5B, $45 \mathrm{~min}$ after the addition of cycloheximide cyclin D1 protein levels dropped almost to basal level, and after
60 min basal level was reached. There were no differences in the decay rates in the presence or absence of LY294002. From this we conclude that the cyclin D1 protein is rather unstable, its half-life being less than $45 \mathrm{~min}$ irrespective of the presence or absence of LY294002. Thus, the observed decrease in steady-state levels after $4-6 \mathrm{~h}$ in the presence of LY294002 is not likely to have been caused by reduced stability of the cyclin D1 protein.

\section{Discussion}

Upregulation of cyclin D1 expression is the first cell cycle-related event after growth-factor stimulation of quiescent cells. In MCF-7 breast cancer cells, moderate overexpression of cyclin D1 has been shown to be sufficient for cell growth under low-serum conditions, establishing cyclin D1 as the key mediator of G1/S-phase transition (Zwijsen et al. 1996). However, the signaltransduction pathways regulating cyclin D1 expression are still poorly understood. Here we demonstrate that the PI3-K signaling pathway, besides being able to activate the cyclin D1 promoter, is involved in post-transcriptional regulation of cyclin D1, stabilizing the $4.5 \mathrm{~kb}$ cyclin D1 mRNA. Inhibition of PI3-K activity by LY294002 clearly reduces the half-life of this mRNA species, whereas the minor $1.5 \mathrm{~kb}$ cyclin D1 mRNA is much less affected. This stabilizing influence of PI3-K is not a general phenomenon for all unstable mRNAs, since inhibition of PI3-K has no effect at all on c-myc mRNA stability and has an opposite (stabilizing) effect on c-fos and c-jun mRNAs. PI3-K does not seem to play a role in regulating cyclin D1 protein stability in our MCF-7 cell model system.

In several experiments we observed that the destabilizing effect of LY294002 was more pronounced for the cyclin D1 protein level than it was for the mRNA level. This could not be explained by an additional effect of LY294002 on protein stability besides mRNA stability, since we have clearly shown that LY294002 does not influence cyclin D1 protein stability. Furthermore, LY294002 predominantly affects the $4.5 \mathrm{~kb}$ transcript and hardly influences the stability of the $1.5 \mathrm{~kb}$ mRNA species. When both mRNAs are translated with an equal efficiency, giving rise to the same protein, the destabilizing effect would be expected to be less clear for the protein level than for the mRNA level. A possible explanation is that the $1.5 \mathrm{~kb}$ messenger is not, or is very inefficiently, translated, so that almost all cyclin D1 protein is derived from the $4.5 \mathrm{~kb}$ mRNA. It may even be that not all of the $4.5 \mathrm{~kb}$ cyclin D1 mRNA is translated, and that the protein is derived from a restricted pool of this longer mRNA species. Whether or not a difference in translation efficiency between the two cyclin D1 mRNAs exists, and how this is brought about, requires further investigation.

PI3-K-dependent signaling routes have been implicated in the regulation of cyclin D1 expression levels in a limited 
number of earlier reports. In NIH3T3 fibroblasts, a PI3-K-dependent signaling route has also been reported to be involved in regulation of cyclin D1 mRNA stability (Hashemolhosseini et al. 1998). This pathway encompasses $\mathrm{p} 70^{\mathrm{S} 6 \mathrm{~K}}$, a known downstream target of PI3-K. In this study two cyclin D1 mRNAs were described, one of them being the $4.5 \mathrm{~kb}$ species, also found in MCF-7 cells, the other one being about $4 \mathrm{~kb}$ in length. The shorter form of $1.5 \mathrm{~kb}$ was not mentioned in this study. The half-lives of both messengers were diminished by treatment of the cells with rapamycin, a specific inhibitor of $\mathrm{p} 70^{\mathrm{S} 6 \mathrm{~K}}$. In addition, an effect of this $\mathrm{PI} 3-\mathrm{K} / \mathrm{p} 70^{\mathrm{S} 6 \mathrm{~K}}$-dependent pathway on cyclin D1 protein stability was also claimed. However, this effect is much less clear, and the authors found an unusually long half-life (about $2 \mathrm{~h}$ ) of the cyclin D1 protein in these experiments. Besides regulation of cyclin D1 mRNA and protein stability, PI3-K-mediated regulation of translation of cyclin D1 mRNA has also been described. Muise-Helmericks et al. (1998) have described an effect of a PI3-K-dependent signaling route on the expression level of D-type cyclins in MCF-7 cells. This concerns the effect of herbimycin $\mathrm{A}$, one of the ansamycins, which causes a reduction in the synthetic rate of D-type cyclins prior to changes in mRNA expression. Since (in our experiments) LY294002 clearly influences the steady-state level of cyclin D1 mRNA, this effect is probably unrelated to our findings. A stabilizing influence of activation of PI3-K on a specific mRNA species has been reported before. Ionomycin-induced stabilization of interleukin (IL)-3 mRNA in mast cells is counteracted by the PI3-K inhibitor wortmannin. c-Jun $N$-terminal kinase (JNK) was shown to be the downstream target of PI3-K required for this stabilization. The cis-acting elements were shown to be so-called AU-rich regions (AREs) in the 3'-UTR (Ming et al. 1998). These AREs contain clusters of AUUUA pentamer repeats, which are well-known instability determinants for mRNAs. They are often present in the 3'-UTRs of short-lived, rapidly regulated mRNAs, such as the mRNAs for the cytokines IL-1 (Kastelic et al. 1996), IL-2 (Henics et al. 1994) and IL-3 (Mayo et al. 1995), granulocyte-macrophage colonystimulating factor (GM-CSF) (Esnault et al. 1998), tumor necrosis factor- $\alpha$ (TNF- $\alpha$ ) (Wang et al. 1997), and for the early genes c-fos (Chagnovich \& Cohn 1997), c-jun (Peng et al. 1996) and c-myc (Chagnovich \& Cohn 1997). The AREs have been shown to be responsible for the short half-lives of these transcripts. Several studies have shown that mutant mRNAs, for example GM-CSF (Esnault et al. 1998) or epidermal growth-factor receptor (McCulloch et al. 1998), which lack their natural AREs have increased half-lives. Moreover, linking of the $3^{\prime}$-UTRs of such unstable mRNAs to coding sequences of, for example, the luciferase or $\beta$-globin mRNAs, severely reduces the half-lives of these normally very stable messengers (Wang et al. 1997). The $4.5 \mathrm{~kb}$ cyclin D1 mRNA species contains about $3 \mathrm{~kb}$ of $3^{\prime}-\mathrm{UTR}$ which is absent from the $1.5 \mathrm{~kb}$ transcript. The $5^{\prime}-\mathrm{UTR}$ and coding region are identical in both mRNAs. The 3'-UTR contains six AUUUA repeats clustered in a region of $420 \mathrm{bp}$ (Motokura et al. 1991). By analogy with what has been found for the IL-3 mRNA, the AU-rich regions may constitute the cis-acting elements required for PI3-K-mediated stabilization of the longer cyclin D1 transcript. Current investigations aim to determine whether or not this is the case.

Some evidence indicates that (over)expression of shorter variants of cyclin D1 mRNA, lacking (part of) the $3^{\prime}-\mathrm{UTR}$, is correlated with transformation and malignancy. Several studies have reported on the existence of mutant cyclin D1 mRNA species in malignant cells of leukemia patients (Withers et al. 1991, Seto et al. 1992, Hosokawa et al. 1998). These mutations are either deletions or truncations caused by genomic deletion or chromosomal translocation. In all cases the AREs are no longer present in the cyclin D1 transcripts. However, in these studies no experiments were performed to determine the effects of these mutations on cyclin D1 mRNA stability. The MDA MB-453 breast cancer cell line has been reported to possess a normal and a truncated copy of the cyclin D1 gene. The truncated copy is amplified threefold, resulting in overexpression of a short cyclin D1 mRNA which corresponds to the $1.5 \mathrm{~kb}$ species in MCF-7 cells. This mRNA has a longer half-life than its $4.5 \mathrm{~kb}$ counterpart, indicating that sequences in the 3'-UTR influence cyclin D1 mRNA stability (Lebwohl et al. 1994). PI3-K-mediated stabilization of cyclin D1 mRNA may account for the observed decrease in cyclin D1 steady-state levels when LY294002 is added to the cells, irrespective of the presence and nature of transcriptional activators.

As summarized in the model in Fig. 6, the hormones IGF-I, EGF and E2 as well as the phorbol ester TPA are all capable of activating the cyclin D1 promoter, each via their own responsive element. E2, in complex with its receptor, binds to the ERE (Altucci et al. 1996), whereas TPA and EGF activate the p42/44 MAP kinases, which results in increased expression of the early response genes c-fos and c-jun. The c-fos and c-jun proteins, in turn, form heterodimeric complexes and bind to the AP-1 binding site (Albanese et al. 1995, Watanabe et al. 1996). IGF-I activates PI3-K, which, as we recently showed, is able to induce cyclin D1 promoter activity via a pathway involving the small GTPases Rac and cdc42 on the one hand (submitted for publication), and stabilizes the $4.5 \mathrm{~kb}$ cyclin D1 mRNA on the other. Although transcriptional activation of the cyclin D1 promoter by E2, EGF and TPA does not involve PI3-K activity, the steady-state levels of cyclin D1 mRNA do not become elevated when LY294002 is present, since basal PI3-K activity is required for stabilization of the $4.5 \mathrm{~kb}$ mRNA. This model may explain the fact that the ras-raf-MAP kinase signaling route is considered to be the essential pathway for inducing proliferation in many cell types. In these studies, often 


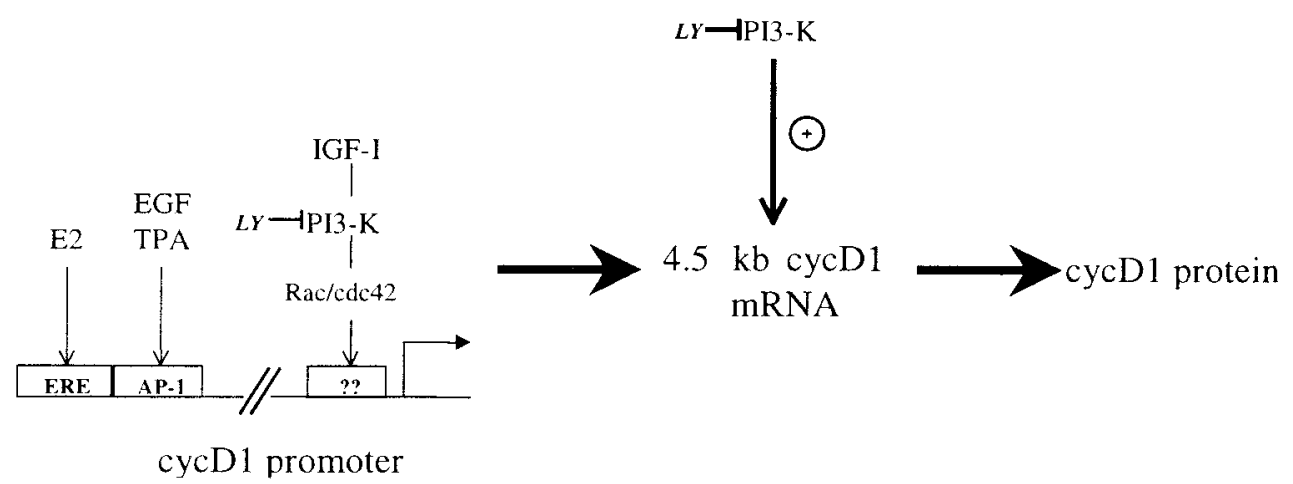

Figure 6 Schematic representation of a model explaining LY-mediated inhibition of cyclin D1 expression induced by different stimulators. Inhibition of PI3-K activity by LY294002 not only blocks signaling to the cyclin D1 promoter (e.g. by IGF-I) but also destabilizes the predominant $4.5 \mathrm{~kb}$ cyclin D1 mRNA. This leads to lower cyclin D1 steady-state levels. See the text for further discussion.

the effects only of specific MEK1/MAP kinase inhibitors have been determined. When the MAP kinases are important in transcriptional activation of the cyclin D1 promoter, as is the case for TPA and EGF in our MCF-7 cell system, these MAP kinase inhibitors will undoubtedly inhibit the proliferative response. Since, however, in most of these studies specific PI3-K inhibitors have not been used, the possibility that that a certain basal level of PI3-K activity is necessary for proliferation as well cannot be excluded. Furthermore, some inhibitors of the ras-rafMAP kinase route, e.g. the farnesyltransferase inhibitor and the ansamycins, geldamycine and herbimycin A, are, according to some recent reports (Muise-Helmericks et al. 1998, Law et al. 1999), also capable of inhibiting the PI3-K pathway. Therefore, inhibition of proliferation by these agents can no longer be considered as evidence for the exclusive importance of the MAP kinase pathway for proliferation.

\section{Acknowledgements}

We would like to thank Dr David Beach for providing the cyclin D1 probe, and Dr Rolf Müller for the kind gift of the cyclin D1 promoter-luciferase construct. This work was supported by the Nederlandse Kankerbestrijding (Dutch Cancer Foundation; Grant UU 98-1701).

\section{References}

Albanese C, Johnson J, Watanabe G, Eklund N, Vu D, Arnold A \& Pestell RG 1995 Transforming p21 ras mutants and c-Ets-2 activate the cyclin D1 promoter through distinguishable regions. Journal of Biological Chemistry 270 23589-23597.

Altucci L, Addeo R, Cicatiello L, Dauvois S, Parker MG, Truss M, Beato M, Sica V, Bresciani F \& Weisz A 1996 17 $\beta$-Estradiol induces cyclin D1 gene transcription, p36D1-p34cdk4 complex activation and $\mathrm{p} 105 \mathrm{Rb}$ phosphorylation during mitogenic stimulation of G1-arrested human breast cancer. Oncogene 12 2315-2324.

Arcaro A \& Wymann MP 1993 Wortmannin is a potent phosphatidylinositol 3-kinase inhibitor: the role of phosphatidylinositol 3,4,5-trisphosphate in neutrophil responses. Biochemical Journal 296 297-301.

Backer JM, Myers MG Jr, Sun XJ, Chin DJ, Shoelson SE, Miralpeix M \& White MF 1993 Association of IRS-1 with the insulin receptor and the phophatidylinositol 3'-kinase. Journal of Biological Chemistry 268 8204-8212.

Baltensperger K, Kozma LM, Cherniack AD, Klarlund JK, Chawla A, Banerjee U \& Czech MP 1993 Binding of the ras activator son of sevenless to insulin receptor substrate-1 signaling complexes. Science $2601950-1952$.

van der Burg B, Rutteman GR, Blankenstein MA, de Laat SW \& van Zoelen EJJ 1988 Mitogenic stimulation of human breast cancer cells in a growth factor-defined medium: synergistic action of insulin and estrogen. Journal of Cellular Physiology 134 101-108.

Burgering BM \& Coffer PJ 1995 Protein kinase B (c-Akt) in phosphatidylinositol-3-OH kinase signal transduction. Nature 376 599-602.

Chagnovich D \& Cohn SL 1997 Activity of a 40 kDa RNA-binding protein correlates with MYCN and c-fos mRNA stability in human neuroblastoma. European Journal of Cancer 33 2064-2067.

Cheatham B, Vlahos CJ, Cheatham L, Wang L, Blenis J \& Kahn CR 1994 Phosphatidylinositol 3-kinase activation is required for insulin stimulation of pp70 S6 kinase, DNA synthesis, and glucose transporter translocation. Molecular and Cellular Biology 14 4902-4911.

Chou MM \& Blenis J 1996 The $70 \mathrm{kDa}$ S6 kinase complexes with and is activated by the Rho family $G$ proteins Cdc42 and Rac1. Cell 85 573-583.

Cobb MH \& Goldsmith EJ 1995 How MAP kinases are regulated. Journal of Biological Chemistry 270 14843-14846.

Dudley DT, Pang L, Decker SJ, Bridges AJ \& Saltiel AR 1995 A synthetic inhibitor of the mitogen-activated protein kinase cascade. PNAS 92 7686-7689.

Dufourny B, Alblas J, van Teeffelen HAAM, van Schaik FMA, van der Burg B, Steenbergh PH \& Sussenbach JS 1997 Mitogenic signaling of insulin-like growth factor I in MCF-7 human breast cancer cells requires phosphatidylinositol 3-kinase and is independent of mitogenactivated protein kinase. Journal of Biological Chemistry 272 31163-31171. 
Esnault S, Jarzembowski JA \& Malter JS 1998 Stabilization of granulocyte-macrophage colony-stimulating factor RNA in a human eosinophil-like cell line requires the AUUUA motifs. Proceedings of the Association of American Physicians 110 575-584.

Filmus J, Robels AL, Shi W, Wong MJ, Colombo LL \& Conti CJ 1994 Induction of cyclin D1 overexpression by activated ras. Oncogene 9 3627-3633.

Hashemolhosseini S, Nagamine Y, Morley SJ, Desrivieres S, Mercep L \& Ferrari S 1998 Rapamycin inhibition of the G1 to S transition is mediated by effects on cyclin D1 mRNA and protein stability. Journal of Biological Chemistry 273 14424-14429.

Henics T, Sanfridson A, Hamilton BJ, Nagy E \& Rigby WF 1994 Enhanced stability of interleukin-2 mRNA in MLA 144 cells. Possible role of cytoplasmic AU-rich sequence-binding proteins. Journal of Biological Chemistry 269 5377-5383.

Hosokawa Y, Suzuki R, Joh T, Maeda Y, Nakamura S, Kodera Y, Arnold A \& Seto M 1998 A small deletion in the $3^{\prime}$-untranslated region of the cyclin D1 PRAD1/bcl-1 oncogene in a patient with chronic lymphocytic leukemia. International Journal of Cancer $\mathbf{7 6}$ 791-796.

Izumi T, White MF, Kadowaki T, Takaku F, Akanuma Y \& Kasuga M 1987 Insulin-like growth factor I rapidly stimulates tyrosine phosphorylation of a Mr 185000 protein in intact cells. Journal of Biological Chemistry 262 1282-1287.

Karey KP \& Sirbasku DA 1988 Differential responsiveness of human breast cancer cell lines MCF-7 and T47D to growth factors and 17ß-estradiol. Cancer Research 48 4083-4092.

Kastelic T, Schnyder J, Leutwiler A, Traber R, Streit B, Niggli H, MacKenzie A \& Cheneval D 1996 Induction of rapid IL-1 beta mRNA degradation in THP-1 cells mediated through the AU-rich region in the $3^{\prime} \mathrm{UTR}$ by a radicicol analogue. Cytokine 8 751-761.

Law BK, Nørgaard P, Gnudi L, Kahn BB, Poulson HS \& Moses HL 1999 Inhibition of DNA synthesis by a farnesyltransferase inhibitor involves inhibition of the p70(s6k) pathway. Journal of Biological Chemistry 274 4743-4748.

Lebwohl DE, Muise-Helmericks R, Sepp-Lorenzino L, Serve S, Timaul M, Bol R, Borgen P \& Rosen N 1994 A truncated cyclin D1 gene encodes a stable mRNA in a human breast cancer cell line. Oncogene 9 1925-1929.

Liu J, Chao J, Jiang M, Ng S, Yen JJ \& Yang-Yen H 1995 Ras transformation results in an elevated level of cyclin D1 and acceleration of G1 progression in NIH 3T3 cells. Molecular and Cellular Biology 15 3654-3663.

McCulloch RK, Walker CE, Chakera A, Jazayeri J \& Leedman PJ 1998 Regulation of EGF-receptor expression by EGF and TGF alpha in epidermoid cancer cells is cell type-specific. International Journal of Biochemistry and Cell Biology 30 1265-1278.

Mayo MW, Wang XY, Algate PA, Arana GF, Hoyle PE, Steelman LS \& McCubrey JA 1995 Synergy between AUUUA motif disruption and enhancer insertion results in autocrine transformation of interleukin-3-dependent hematopoietic cells. Blood 86 3139-3150.

Ming X-F, Kaiser M \& Moroni C 1998 c-jun N-terminal kinase is involved in AUUUA-mediated interleukin-3 mRNA turnover in mast cells. EMBO Journal 17 6039-6048.

Motokura T, Bloom T, Kim HG, Jüppner H, Ruderman JV, Kronenberg HM \& Arnold A 1991 A novel cyclin encoded by a bc/1-linked candidate oncogene. Nature 350 512-515.

Muise-Helmericks RC, Grimes HL, Bellacosa A, Malstrom SE, Tsichlis PN \& Rosen N 1998 Cyclin D expression is controlled post-transcriptionally via a phosphatidylinositol 3-kinase Akt-dependent pathway. Journal of Biological Chemistry 273 29864-29872.

Müller R 1995 Trancriptional regulation during the mammalian cell cycle. Trends in Genetics 11 173-178.
Myers MG Jr, Backer JM, Sun XJ, Shoelson S, Hu P, Schlessinger J, Yoakim M, Schaffhausen B \& White MF 1992 IRS-1 activates phosphatidylinositol $3^{\prime}$-kinase by associating with src homology 2 domains of p85. PNAS 89 10350-10354.

Nigg EA 1995 Cyclin-dependent protein kinases: key regulators of the eukaryotic cell cycle. BioEssays 17 471-480.

Peng SS, Chen CY \& Shyu AB 1996 Functional characterization of a non-AUUUA AU-rich element from the c-jun proto-oncogene mRNA: evidence for a novel class of AU-rich elements. Molecular and Cellular Biology 16 1490-1499.

Price DJ, Grove JR, Calvo V, Avruch J \& Bierer BE 1992 Rapamycin-induced inhibition of the 70-kilodalton S6 protein kinase. Science 257 973-977.

Ross J 1995 mRNA stability in mammalian cells. Microbiology Reviews 59 423-450.

Sanchez I \& Dynlacht BD 1996 Transcriptional control of the cell cycle. Current Opinion in Cell Biology 8 318-324.

Seto M, Yamamoto K, Iida S, Akao Y, Utsumi KR, Kubonishi I, Miyoshi I, Ohtsuki T, Yawata Y, Namba M, Motokura T, Arnold A, Takahashi T \& Ueda R 1992 Gene rearrangement and overexpression of PRAD1 in lymphoid malignancy with $\mathrm{t}(11 ; 14)(\mathrm{q} 13 ; \mathrm{q} 32)$ translocation. Oncogene 7 1401-1406.

Shemer J, Adamo M, Wilson GL, Heffez D, Zick Y \& LeRoith D 1987 Insulin and insulin-like growth factor-I stimulate a common endogenous phosphoprotein substrate (pp185) in intact neuroblastoma cells. Journal of Biological Chemistry 262 15476-15482.

Skolnik EY, Batzer A, Li N, Lee CH, Lowenstein E, Mohammadi M, Margolis B \& Schlessinger J 1993a The function of GRB2 in linking the insulin receptor to ras signaling pathways. Science $\mathbf{2 6 0}$ 1953-1955.

Skolnik EY, Lee CH, Batzer A, Vicenti LM, Zhou M, Daly R, Myers MJ Jr, Backer JM, Ullrich A, White MF \& Schlessinger J $1993 b$ The SH2/SH3 domain-containing protein GRB2 interacts with tyrosine-phosphorylated IRS1 and Shc: implications for insulin control of ras signalling. EMBO Journal 12 1929-1936.

Vlahos CJ, Matter WF, Hui KY \& Brown RF 1994 A specific inhibitor of phosphatidylinositol 3-kinase, 2-(4-morpholinyl)-8phenyl-4H-1-benzopyran-4-one (LY294002). Journal of Biological Chemistry 269 5241-5248.

Wang E, Ma WJ, Aghajanian C \& Spriggs DR 1997 Posttranscriptional regulation of protein expression in human epithelial carcinoma cells by adenine-uridine-rich elements in the $3^{\prime}$-untranslated region of tumor necrosis factor-alpha messenger RNA. Cancer Research 57 5426-5433.

Watanabe G, Lee RJ, Albanese C, Rainey WE, Batlle D \& Pestell RG 1996 Angiotensin II activation of cyclin D1-dependent kinase activity. Journal of Biological Chemistry 271 22570-22577.

Weinberg RA 1995 The retinoblastoma protein and cell cycle control. Cell 81 323-330.

Welcker M, Lukas J, Strauss M \& Bartek J 1996 Enhanced protein stability: a novel mechanism of D-type cyclin over-abundance identified in human sarcoma cells. Oncogene 13 419-425.

Withers DA, Harvey RC, Faust JB, Melnyk O, Carey K \& Meeker TC 1991 Characterization of a candidate bcl-1 gene. Molecular and Cellular Biology 11 4846-4853.

Xiong Y, Connolly T, Futcher B \& Beach D 1991 Human D-type cyclin. Cell 65 691-699.

Zwijsen RM, Klompmaker R, Wientjes EB, Kristel PM, van der Burg B \& Michalides RJ 1996 Cyclin D1 triggers autonomous growth of breast cancer cells by governing cell cycle exit. Molecular and Cellular Biology 16 2554-2560.

Received 16 December 1999

Accepted 31 March 2000 